\title{
Lesbian, Gay, Bisexual, and Transgender (LGBT) Issues in Dental School Environments: Dental Student Leaders' Perceptions
}

\author{
Joan I. Anderson, D.D.S.; April N. Patterson, D.D.S.; Henry J. Temple, D.D.S.; \\ Marita Rohr Inglehart, Dr. phil. habil.
}

Abstract: The objectives of the study reported in this article were to assess dental student leaders' perceptions of educational efforts concerning lesbian, gay, bisexual, and transgender (LGBT) topics and the cultural climate concerning LGBT issues in dental schools in the United States and Canada. In addition, the perceptions of student leaders who self-identified as belonging to the LGBT community and of students with a heterosexual orientation were compared. Data were collected from 113 dental student leaders from twenty-seven dental schools in the United States and three in Canada. Fifty student leaders were females, and sixty-two were males. Only 13.3 percent of the respondents agreed that their dental education prepared them well to treat patients from LGBT backgrounds. The more the student leaders believed that their university has an honest interest in diversity, the better they felt prepared by their dental school program to treat patients from LGBT backgrounds $(r=.327 ; \mathrm{p}<.001)$. The better they felt prepared, the more they perceived the clinic environment as sensitive and affirming for patients with different sexual orientations $(\mathrm{r}=.464 ; \mathrm{p}<.001)$. The more they reported that dental schools' administrations create a positive environment for students with LGBT orientations, the more they agreed that persons can feel comfortable regardless of their sexual orientation $(r=.585 ; \mathrm{p}<.001)$. In conclusion, the findings indicate that dental school administrators play an important role in ensuring that future care providers are well prepared to treat patients from LGBT backgrounds and that staff, faculty, students, and patients from these backgrounds are not discriminated against.

Dr. Anderson is practicing dentistry in Augusta, GA; Dr. Patterson is a graduate student in the AEGD Program, School of Dentistry, University of Michigan; Dr. Temple is Clinical Lecturer, Department of Periodontics and Oral Medicine, School of Dentistry, University of Michigan; and Dr. Inglehart is Associate Professor, Department of Periodontics and Oral Medicine, School of Dentistry and Adjunct Associate Professor, Department of Psychology, College of Literature, Sciences, and Arts, University of Michigan. Direct correspondence and requests for reprints to Dr. Marita Rohr Inglehart, Department of Periodontics and Oral Medicine, School of Dentistry, University of Michigan, 1011 North University Avenue, Ann Arbor, MI 48109-1078; 734-763-8073 phone; 734-763-5503 fax; mri@umich.edu.

Key words: sexual orientation, homosexuality, dental education, climate, dentistry

Submitted for publication 5/25/08; accepted 10/11/08

$\mathrm{R}$ ecent research has documented that there are substantial numbers of adults in the United States who identify themselves as gay, lesbian, or bisexual and that the number of same sex couples living together is increasing. ${ }^{1,2}$ Dental education needs to prepare future dental care providers to provide care for patients from non-heterosexual backgrounds to be able to treat these patients in a professional manner. This study explored how dental student leaders in the United States and Canada perceive their education concerning providing care for lesbian, gay, bisexual, or transgender (LGBT) patients (Aim 1) and how they perceive the climate in their schools concerning these issues (Aim 2). The term "climate" is defined in this context as the shared beliefs and values that guide the thinking and behavior of members of the dental school community. ${ }^{3}$ In addition, a comparison of the perceptions of student leaders who self-identified as LGBT with those who did not identify as LGBT was performed (Aim 3).

In 1994, Laumann et al. reported that around 1.3 to 4.1 percent of female adults and 2.7 to 4.9 percent of male adults self-reported as being gay or lesbian. ${ }^{1}$ According to the U.S. census in the year 2000, 601,209 lesbian and gay couples and thus over 1.2 million U.S. adults reported living together in an unmarried partner relationship - which represents about .4 percent of the overall U.S. population. ${ }^{1}$ This number only included those gays and lesbians that reported living together as unmarried couples and did not include any single or non-committed gay and lesbian people, nor did it include couples unwilling to self-identify as gay or lesbian to polltakers. Smith and Gates reported that the 2000 census indicated 
that lesbian and gay couples lived in 99.3 percent of U.S. counties and that only twenty-two of the 3,219 counties in the United States did not report any gay or lesbian couples. ${ }^{2}$

Research concerning LGBT issues in dental school environments is scarce. One exception is a study by More et al. from the year 2004. ${ }^{4}$ These researchers found that 62 percent of student affairs administrators were aware of lesbian and gay students at their schools and 45 percent were aware of patients in their school clinics who identified as sexual minorities. However, 49 percent reported that their curriculum included only two hours or less of information relating to issues of sexual minorities.

In addition to considering the extent to which LGBT-related issues are addressed in the formal dental school curriculum, it is crucial to also ensure that the dental school climate is inclusive and that students, staff, faculty members, and patients from LGBT backgrounds are not subjected to discrimination. Over a decade ago, Machen, a former dean of the University of Michigan School of Dentistry and the chairperson of the LGBT nondiscrimination task force at that university, reported that he personally did not know even one "out" LGBT individual in his dental school. ${ }^{5}$ He decided to learn as much as he could about the LGBT culture and found the dental school environment was not perceived to be adequately comfortable and supportive for LGBT students, faculty members, and staff to "come out." He charged universities with the task of providing a place for positive change in society, and argued that people need to step forward in their dental schools for this change to happen.

Improving the cultural climate for LGBT persons could include having an LGBT student group in an academic unit. Research by Townsend et al. in medical schools found that medical students were more likely to disclose their sexual orientation if their school had an LGB support group. ${ }^{6}$ Two-thirds of the students in the Townsend et al. study reported that they knew a faculty member they could talk to about LGB issues, but only 9 percent of these faculty members held a position in a multicultural affairs/ LGBT office that existed to address the needs and concerns of sexual minority students.

In addition to gaining a better understanding of the situation that LGBT students, staff, and faculty members face in dental schools, it is also crucial to gain a better understanding of how culturally sensitive care can be provided to LGBT patients. In 2001, the Gay and Lesbian Medical Association published a companion document to Healthy People 2010 describing concerns that health providers should be aware of in treating sexual minorities. ${ }^{7}$ Access to care is a problem for sexual minorities, as it is for other minority groups in the United States. However, sexual minorities often face an additional barrier because they cannot get health insurance through their partners. In addition, this document described health disparity issues for patients from LGBT backgrounds in the areas of nutrition, weight, consumption of alcohol, use of tobacco products, and domestic violence. For example, Ridner et al. found in 2006 that the smoking rates of self-identified lesbian or bisexual women in college was 4.9 times higher than heterosexual women and that these students were 10.7 times more likely to drink alcohol compared to students who did not self-identify as being lesbian or bisexual. ${ }^{8}$ Given that the use of tobacco products and the consumption of alcohol are related to patients' oral health, it is important for dental care providers to be aware of the high prevalence of these health-related issues in their patients from LGBT backgrounds.

The largest problem that the Healthy People 2010 companion document by the Gay and Lesbian Medical Association identified was the lack of research on LGBT-related health issues. Compared to the percentages of LGBT persons in the United States, the percentages of health-related publications concerning patients from LGBT backgrounds is strikingly low. For example, in 2002, Boehmer found that only .1 percent of articles on Medline addressed LGBT issues in the last twenty years. ${ }^{9}$ Of these articles, 56 percent were on sexually transmitted diseases, 52 percent were specifically related to HIV or AIDS, and only 39 percent were on non-disease-specific factors. It is therefore not surprising that most of the evidence reported by the Gay and Lesbian Medical Association was based on a limited number of studies.

One problem that researchers face in the LGBT community is related to the fact that many patients from LGBT backgrounds do not disclose their sexual orientation to their health care providers. ${ }^{10}$ Research by Dinkel et al. in 2007 found that homophobia is still a problem that causes many LGBT patients to not disclose their sexual orientation to their health care providers out of fear of discrimination or substandard care. ${ }^{11}$ However, hesitancy to disclose sexual orientation can have an adverse psychological impact on patient-provider interaction; research has shown that "coming out" to a health care provider, even if not discussing sexual health, makes the patient feel 
more like a whole person. ${ }^{12}$ Cultural competence is therefore an important tool to create a supportive relationship between health care providers and patients. ${ }^{10}$ For example, McKelvey et al. reported in 1999 that medical and nursing students who had less knowledge about sexual minorities (and sex in general) had the worst attitudes toward sexual minorities and topics relating to sexual minorities. ${ }^{13}$ Research by Elam et al. in 2001 found that the presence of diverse students was a key factor in making the overall student population more comfortable with diversity and in making them aware that experiencing diversity contributed to their medical school education. ${ }^{14}$

In summary, two conclusions can be drawn from the existing, and relatively sparse, research on LGBT students in health profession programs. First, dental and dental hygiene educators should realize that their educational efforts need to prepare future practitioners to provide the best possible care for all patients, including patients from LGBT backgrounds. Second, dental school environments must become safe places for students, staff, faculty members, and patients from LGBT backgrounds.

Our study therefore had three aims. Aim 1 focused on assessing the perceptions and experiences of dental student leaders in U.S. and Canadian dental schools concerning the extent and the quality of their schools' educational efforts to prepare future practitioners in such a way that they can respond to the health care needs and concerns of LGBT patients. Aim 2 assessed student leaders' perceptions concerning the nature of their dental school climate for LGBT students, staff, faculty members, and patients. Aim 3 was to compare the perceptions and experiences of respondents who self-identified as LGBT versus those of respondents who did not identify themselves as LGBT.

\section{Methods}

This study was approved by the Institutional Review Board for the Health Sciences at the University of Michigan, Ann Arbor, MI (\#HUM00014317).

Data were collected from 113 dental student leaders (44.6 percent female and 55.4 percent male). The respondents attended predoctoral dental programs at twenty-seven dental schools in the United States and three dental schools in Canada. Five respondents were in their first year, thirty-eight in their second year, thirty-four in their third year, and thirty-four in their fourth year of dental education.
Sixteen students from nine different dental schools self-identified as LGBT.

An email with information about this study was sent in August 2007 to the academic affairs deans and multicultural affairs directors/deans of the fifty-two dental schools in the United States and ten dental schools in Canada whose email addresses could be located. The email asked these individuals to "forward an email and a weblink for a survey to your student leaders within the predoctoral dental school program." The email defined who should be considered a student leader-namely, "anyone on the student council at your dental school, leaders of minority student groups, and anyone that may be involved in an LGBT group at your school." Sixtysix students responded to this first email. In October 2007, a follow-up email was sent, and an additional forty-seven students responded. Responding to the survey took approximately seven to ten minutes.

The web-based survey was adapted from a survey originally developed for the first cultural audit at the University of Michigan School of Dentistry in $1994^{15}$ and used in this school's follow-up cultural audit in 2006-07. ${ }^{16} \mathrm{~A}$ committee made up of dental and dental hygiene students, graduate students, staff, and faculty members designed the original survey with the goal of capturing students' and staff and faculty members' perceptions of the cultural climate in their dental school. The original survey was piloted with small groups of students and staff and faculty members and was then used in the original cultural audit in $1994-95^{15}$ as well as in a follow-up audit in 2006-07. ${ }^{16}$

While the original survey included questions about educational experiences and cultural climate perceptions concerning seven different issues (ethnic/racial differences, gender, socioeconomic status, age, religious affiliation, special needs/abilities, and sexual orientation), the survey used in our study included only questions concerning LGBT issues. It consisted of four parts. Part 1 contained questions about the students' background such as their gender, year in school, and dental school attended. Part 2 focused on the students' perceptions of their education about LGBT issues. Part 3 consisted of questions about their schools' cultural climate in general and specifically about the cultural climate concerning LGBT issues. Part 4 asked about the student leaders' own sexual orientation, their knowledge of LGBT persons in their academic units, and their own observations and experiences of behavior towards LGBT persons. 
The data were analyzed with SPSS (SPSS Inc., SPSS 14.0, Student Version for Windows, Prentice Hall, 2006). Analyses of the responses concerning the educational experiences and LGBT-related observations and thoughts were performed on both an individual level and a school level. This second part of the analysis was performed because the number of student leaders from particular schools ranged from one to twenty-four students. Given that several students from particular schools responded, the responses of these students from one school might bias the overall results for all thirty schools. The responses of the students from each school were therefore averaged, and the average scores from each of the thirty schools were then used in the schoollevel analyses.

However, for comparing the responses of students who self-identified as LGBT versus those who did not, individual-level data were analyzed. Descriptive statistics are used to inform the reader about the frequency distributions and the central tendency and variability of the data. Comparisons of the average responses of the LGBT-identified vs. not-identified students were conducted with independent sample ttests. Pearson correlations were computed to analyze the relationship between the student leaders' descriptions of their dental education concerning LGBT issues and their perceptions of the overall cultural climate and LGBT-specific climate issues.

\section{Results}

The results are based on data from 113 dental student leaders (44.6 percent female and 55.4 percent male) in thirty dental schools (twenty-seven U.S. schools and three Canadian schools). The numbers of students from particular schools ranged from one respondent from five schools to a maximum of twenty-four respondents from one school. On average, 3.77 students answered from each of the thirty schools. In addition, the students were from all different educational years in these schools (first year: five; second year: thirty-eight; third year: thirtyfour; fourth year: thirty-four; missing data: two). As described in the statistical analysis section, the responses of students from one school were averaged for school-based analyses of a) the LGBT-related educational efforts/experiences in different schools and $b$ ) the perceptions of the cultural climate in the different schools; these findings were reported in addition to the reported findings concerning the individual responses. However, for the comparisons of the responses of the sixteen self-identified LGBT student leaders with the responses of the ninety-six student leaders who did not identify as LGBT, individual level analyses were conducted.

The first objective was to assess the student leaders' responses concerning their dental schools' educational efforts to include LGBT-related material in their curricula. Table 1 shows that students in 64.4 percent of the schools $(\mathrm{N}=19 / 30)$ responded neutrally to the statement "My classes prepared me well for treating patients from non-heterosexual backgrounds" and that respondents from seven schools disagreed $(\mathrm{N}=6)$ or strongly disagreed $(\mathrm{N}=1)$ with this statement (23.3 percent). Student leaders in only four schools responded positively to this statement (13.3 percent).

Despite the fact that these responses indicated that students perceive that their schools do not place a high priority on instruction in LGBT issues, respondents from only three schools (13.3 percent) agreed $(\mathrm{N}=2)$ or strongly agreed $(\mathrm{N}=1)$ with the statement "The curriculum should include more education about treating patients from non-heterosexual backgrounds." Student respondents from sixteen schools (53.4 percent) disagreed $(\mathrm{N}=14)$ or disagreed strongly $(\mathrm{N}=2)$ with this statement; respondents from eleven schools (36.7 percent) were neutral.

An analysis of responses to an open-ended follow-up question that asked respondents to list all classes in which they received LGBT-related information was consistent with the preceding findings. As shown in Table 2, student leaders from twenty-three schools (76.7 percent) reported that there is no education about LGBT issues provided in their dental school programs. Student leaders in the other seven schools reported that they have received information in more than one class or educational setting. Respondents from four schools reported that they have received LGBT-related education in behavioral science courses, and respondents from two schools reported that this material had been covered in classes in the basic sciences, in classes concerned with cultural competence, or during problem-based learning. Respondents from one school each mentioned having this material covered in dental specialty classes such as periodontics, prosthodontics, or restorative dentistry or general health-related classes (HIV, Medicine, Pathology).

The second aim focused on the student leaders' perceptions of the overall educational environment and the LGBT-related dental school climate-with 
Table 1. School-based (and individual) responses concerning educational efforts about LGBT curricular content, by number and percentage of total respondents

\begin{tabular}{|c|c|c|c|c|c|c|}
\hline & $\begin{array}{c}1=\text { strongly } \\
\text { disagree }\end{array}$ & $2=$ disagree & $3=$ neutral & 4=agree & $\begin{array}{c}5=\text { strongly } \\
\text { agree }\end{array}$ & $\begin{array}{c}\text { Mean } \\
\text { SD }\end{array}$ \\
\hline \multirow[t]{2}{*}{$\begin{array}{l}\text { My classes prepared me well for treating } \\
\text { patients from non-heterosexual backgrounds. }\end{array}$} & $\begin{array}{l}\mathrm{N}=1 * \\
3.3 \%\end{array}$ & $\begin{array}{l}N=6 \\
20 \%\end{array}$ & $\begin{array}{l}N=19 \\
64.4 \%\end{array}$ & $\begin{array}{l}N=3 \\
10 \%\end{array}$ & $\begin{array}{l}\mathrm{N}=1 \\
3.3 \%\end{array}$ & \multirow[t]{2}{*}{2.92} \\
\hline & $\begin{array}{c}(\mathrm{N}=9 \\
8 \%)^{* *}\end{array}$ & $\begin{array}{l}(\mathrm{N}=25 \\
22.1 \%)\end{array}$ & $\begin{array}{l}(\mathrm{N}=44 \\
38.9 \%)\end{array}$ & $\begin{array}{c}(\mathrm{N}=26 \\
23 \%)\end{array}$ & $\begin{array}{l}(\mathrm{N}=8 \\
7.1 \%)\end{array}$ & \\
\hline \multirow{2}{*}{$\begin{array}{l}\text { The curriculum should include more education } \\
\text { about treating patients from non-heterosexual } \\
\text { backgrounds. }\end{array}$} & $\begin{array}{l}\mathrm{N}=2 \\
6.7 \%\end{array}$ & $\begin{array}{l}\mathrm{N}=14 \\
46.7 \%\end{array}$ & $\begin{array}{c}\mathrm{N}=11 \\
36.7 \%\end{array}$ & $\begin{array}{l}\mathrm{N}=2 \\
10 \%\end{array}$ & $\begin{array}{l}\mathrm{N}=1 \\
3.3 \%\end{array}$ & \multirow[t]{2}{*}{2.57} \\
\hline & $\begin{array}{c}(\mathrm{N}=19 \\
16.8 \%)\end{array}$ & $\begin{array}{l}(\mathrm{N}=38 \\
33.6 \%)\end{array}$ & $\begin{array}{c}(\mathrm{N}=29 \\
25.7 \%)\end{array}$ & $\begin{array}{l}(\mathrm{N}=19 \\
16.8 \%)\end{array}$ & $\begin{array}{l}(\mathrm{N}=8 \\
7.1 \%)\end{array}$ & \\
\hline
\end{tabular}

*The frequencies/percentages not in parentheses are the results for the school-based analyses $(\mathrm{N}=30)$. The school-based average responses were categorized as follows: $\langle 1.5=1 ; 1.5-2.5=2 ;>2.5-3.5=3 ;>3.5-4.5=4 ;>4.5=5$.

**The frequencies/percentages in parentheses are the descriptive information about the individual student $(\mathrm{N}=113)$ responses.

Note: If percentages do not add up to $100 \%$, there are missing data in these responses.

the term "climate" defined in this context as the shared beliefs and values that guide the thinking and behavior of the members of the dental school community. ${ }^{3}$ The survey contained twenty-one questions that focused on the dental school climate in general, the LGBT-related climate, and the student leaders' experiences and observations of climaterelated behavior. A factor analysis of responses to these twenty-one questions (Extraction Method: Principal Component Analysis; Rotation Method: Varimax with Kaiser Normalization) resulted in six factors. The wording of the questions included under these six factors is presented in Table 3. Five items loaded on Factor 1, "General climate perceptions" (Cronbach's alpha=.824); four items loaded on Factor 2, "Faculty and clinics and LGBT issues" (Cronbach's alpha $=.815$ ); four items loaded on Factor 3, "Climate for students with LGBT orientations" (Cronbach's alpha=.747); three items loaded on Factor 4, "Perceptions of discrimination" (Cronbach's alpha=.382); two items loaded on Factor 5, "Student experiences/ observations" (Cronbach's alpha=.514); and three items loaded on the final factor, "Frequency of observed discrimination" (Cronbach's alpha=.493).

Concerning the student leaders' perceptions of the climate in general, respondents in 70 percent of the thirty schools agreed and respondents in 20 percent of the schools strongly agreed with the statement that their university has an honest interest or concern for diversity on campus, and student leaders in 66.7 percent of the schools agreed and 13.3 percent of the schools strongly agreed that their dental school has an honest interest or concern for diversity in their school (see Table 3). The majority of the respondents in the thirty schools said they feel comfortable working in their schools ( 90 percent) and feel comfortable working with instructors/supervisors/patients and other students regardless of their sexual orientation (93.3 percent). However, students in only 66.7 percent of the schools agreed or strongly agreed with the statement that it is easy to feel comfortable in their school for persons regardless of sexual orientation. In addition to providing information about the school-based responses, Table 3 presents the percentages of indi-

Table 2. Frequencies/percentages of schools that present LGBT material in different settings

\begin{tabular}{lcc} 
Class Type & $\begin{array}{c}\text { Number } \\
\text { of Schools }\end{array}$ & $\begin{array}{c}\text { Percentage } \\
\text { of Total } \\
\text { Respondents }\end{array}$ \\
\hline No Classes & 23 & $76.7 \%$ \\
Behavioral Science & 4 & $13.3 \%$ \\
Biological Sciences & 2 & $6.6 \%$ \\
Cultural Competence & 2 & $6.6 \%$ \\
Problem-Based Learning & 2 & $6.6 \%$ \\
Ethics & 1 & $3.3 \%$ \\
HIV & 1 & $3.3 \%$ \\
Medicine & 1 & $3.3 \%$ \\
Pathology & 1 & $3.3 \%$ \\
Periodontics & 1 & $3.3 \%$ \\
Prosthodontics & 1 & $3.3 \%$ \\
Public Health & 1 & $3.3 \%$ \\
Restorative & 1 & $3.3 \%$ \\
\end{tabular}


Table 3. School-based (and student-based) responses concerning the cultural climate

\begin{tabular}{|c|c|c|c|c|c|c|}
\hline & 1 & 2 & 3 & 4 & 5 & Mean \\
\hline \multicolumn{7}{|l|}{ Factor 1: general climate perceptions } \\
\hline $\begin{array}{l}\text { I believe that my university has an honest interest/concern for } \\
\text { diversity on this campus. }\end{array}$ & $\begin{array}{l}0 \% \\
(.9 \%)\end{array}$ & $\begin{array}{l}3.3 \% \\
(.9 \%)\end{array}$ & $\begin{array}{l}0 \% \\
(8.8)\end{array}$ & $\begin{array}{l}70 \% \\
(47.8)\end{array}$ & $\begin{array}{l}20 \% \\
(41.6)\end{array}$ & 4.28 \\
\hline $\begin{array}{l}\text { I believe that my dental school has an honest interest/concern } \\
\text { for diversity in the dental school. }\end{array}$ & $\begin{array}{l}0 \% \\
(.9 \%)\end{array}$ & $\begin{array}{l}3.3 \% \\
(6.2 \%)\end{array}$ & $\begin{array}{c}13.3 \% \\
(18.6 \%)\end{array}$ & $\begin{array}{l}66.7 \% \\
(40.7 \%)\end{array}$ & $\begin{array}{c}13.3 \% \\
(33.6 \%)\end{array}$ & 4.00 \\
\hline I am comfortable working in my dental school. & $\begin{array}{l}0 \% \\
(.9 \%)\end{array}$ & $\begin{array}{l}3.3 \% \\
(4.4 \%)\end{array}$ & $\begin{array}{l}6.7 \% \\
(2.7 \%)\end{array}$ & $\begin{array}{c}40 \% \\
(26.5 \%)\end{array}$ & $\begin{array}{c}50 \% \\
(65.5 \%)\end{array}$ & 4.51 \\
\hline $\begin{array}{l}\text { I feel comfortable working with my supervisor/instructor/ } \\
\text { patients and other students regardless of sexual orientation. }\end{array}$ & $\begin{array}{c}0 \% \\
(1.8 \%)\end{array}$ & $\begin{array}{c}0 \% \\
(1.8 \%)\end{array}$ & $\begin{array}{l}3.3 \% \\
(3.5 \%)\end{array}$ & $\begin{array}{l}43.3 \% \\
(34.5 \%)\end{array}$ & $\begin{array}{c}50 \% \\
(58.4 \%)\end{array}$ & 4.46 \\
\hline $\begin{array}{l}\text { It is easy to feel comfortable in this school for persons } \\
\text { regardless of their sexual orientation. }\end{array}$ & $\begin{array}{c}0 \% \\
(3.5 \%)\end{array}$ & $\begin{array}{l}6.7 \% \\
(9.7 \%)\end{array}$ & $\begin{array}{l}23.3 \% \\
(18.6 \%)\end{array}$ & $\begin{array}{c}66.7 \% \\
(37.1 \%)\end{array}$ & $\begin{array}{c}0 \% \\
(31 \%)\end{array}$ & 3.82 \\
\hline \multicolumn{7}{|l|}{ Factor 2: faculty and clinics and LGBT issues } \\
\hline $\begin{array}{l}\text { The school clinics provide an environment for patients that is } \\
\text { sensitive and affirming to differences by sexual orientation. }\end{array}$ & $\begin{array}{c}0 \% \\
(2.7 \%)\end{array}$ & $\begin{array}{c}0 \% \\
(4.4 \%)\end{array}$ & $\begin{array}{c}30 \% \\
(24.8 \%)\end{array}$ & $\begin{array}{l}63.3 \% \\
(43.4 \%)\end{array}$ & $\begin{array}{c}6.7 \% \\
(23.9 \%)\end{array}$ & 3.82 \\
\hline $\begin{array}{l}\text { The faculty provides equal treatment of patients independent } \\
\text { of the patient's sexual orientation. }\end{array}$ & $\begin{array}{l}0 \% \\
(.9 \%)\end{array}$ & $\begin{array}{l}0 \% \\
(.9 \%)\end{array}$ & $\begin{array}{c}3.3 \% \\
(11.5 \%)\end{array}$ & $\begin{array}{l}66.7 \% \\
(33.6 \%)\end{array}$ & $\begin{array}{c}30 \% \\
(52.2 \%)\end{array}$ & 4.37 \\
\hline $\begin{array}{l}\text { Faculty members encourage students equally to pursue career } \\
\text { development independent of their sexual orientation. }\end{array}$ & $\begin{array}{c}0 \% \\
(3.5 \%)\end{array}$ & $\begin{array}{c}0 \% \\
(2.7 \%)\end{array}$ & $\begin{array}{c}20 \% \\
(20.4 \%)\end{array}$ & $\begin{array}{l}66.7 \% \\
(32.7 \%)\end{array}$ & $\begin{array}{c}13.4 \% \\
(40.7 \%)\end{array}$ & 4.04 \\
\hline $\begin{array}{l}\text { Some faculty members have a condescending attitude toward } \\
\text { members of this group. }\end{array}$ & $\begin{array}{c}6.7 \% \\
(14.2 \%)\end{array}$ & $\begin{array}{l}43.3 \% \\
(35.4 \%)\end{array}$ & $\begin{array}{l}43.3 \% \\
(26.5 \%)\end{array}$ & $\begin{array}{c}6.7 \% \\
(20.4 \%)\end{array}$ & $\begin{array}{c}0 \% \\
(2.7 \%)\end{array}$ & 2.62 \\
\hline \multicolumn{7}{|l|}{ Factor 3: climate for students with LGBT orientations } \\
\hline There is a supportive student community for these students. & $\begin{array}{c}0 \% \\
(3.5 \%)\end{array}$ & $\begin{array}{c}30 \% \\
(27.4 \%)\end{array}$ & $\begin{array}{l}50 \% \\
(31 \%)\end{array}$ & $\begin{array}{c}20 \% \\
(31.9 \%)\end{array}$ & $\begin{array}{c}0 \% \\
(5.3 \%)\end{array}$ & 3.08 \\
\hline $\begin{array}{l}\text { The school environment is one in which these students feel } \\
\text { comfortable and are included. }\end{array}$ & $\begin{array}{c}0 \% \\
(2.7 \%)\end{array}$ & $\begin{array}{l}3.3 \% \\
(8.8 \%)\end{array}$ & $\begin{array}{l}36.7 \% \\
(18.6 \%)\end{array}$ & $\begin{array}{l}56.7 \% \\
(55.8 \%)\end{array}$ & $\begin{array}{c}3.3 \% \\
(12.4 \%)\end{array}$ & 3.68 \\
\hline $\begin{array}{l}\text { These students voice their ideas in meetings and classes as } \\
\text { often as students not belonging to this group. }\end{array}$ & $\begin{array}{l}3.3 \% \\
(7.1 \%)\end{array}$ & $\begin{array}{l}13.3 \% \\
(7.1 \%)\end{array}$ & $\begin{array}{c}30 \% \\
(29.5 \%)\end{array}$ & $\begin{array}{c}50 \% \\
(40.2 \%)\end{array}$ & $\begin{array}{c}3.3 \% \\
(16.1 \%)\end{array}$ & 3.51 \\
\hline $\begin{array}{l}\text { The dental school administration creates a positive } \\
\text { environment for students with non-heterosexual } \\
\text { orientations. }\end{array}$ & $\begin{array}{c}0 \% \\
(2.7 \%)\end{array}$ & $\begin{array}{c}0 \% \\
(3.5 \%)\end{array}$ & $\begin{array}{l}36.7 \% \\
(38.9 \%)\end{array}$ & $\begin{array}{l}63.3 \% \\
(37.2 \%)\end{array}$ & $\begin{array}{c}0 \% \\
(16.8 \%)\end{array}$ & 3.63 \\
\hline
\end{tabular}
orientations.

vidual responses to these questions. A comparison of the school-level and individual responses shows that the school-level responses are less influenced by responses at either end of the school, because they are based on average responses of students in each of the thirty schools.

Responses to the items loading on Factor 2 were concerned with the ways that faculty members and the school clinics respond to LGBT issues. Student leaders in all but one school ( 96.7 percent) agreed that faculty members at their school provide equal treatment of patients independent of the patient's sexual orientation. Respondents in twenty-three of the thirty schools (80.1 percent) indicated that faculty members encourage students equally to pursue career development independent of their sexual orientation. However, only 70 percent of the schools were described as having clinics that provide an environ- ment for patients that is sensitive and affirming to differences by sexual orientation. While the student leaders in half of the schools (50 percent) disagreed or disagreed strongly with the statement that some faculty members have condescending attitudes toward members of the LGBT group, respondents from 43.3 percent of the schools responded neutrally to this statement, and student leaders from two schools (6.7 percent) agreed with this statement.

An analysis of the responses to the items loading on Factor 3 that were more specifically concerned with the climate for LGBT students found that student leaders from only six of the thirty schools (20.0 percent) agreed with the statement that there is a supportive student community for LGBT students at their school, while respondents from nine schools (30.0 percent) disagreed with this statement. Student leaders from the majority of the schools agreed (56.7 
Table 3. School-based (and student-based) responses concerning the cultural climate (continued)

\begin{tabular}{|c|c|c|c|c|c|c|}
\hline & 1 & 2 & 3 & 4 & 5 & Mean \\
\hline \multicolumn{7}{|l|}{ Factor 4: perceptions of discrimination } \\
\hline \multirow[t]{2}{*}{$\begin{array}{l}\text { Others seem to find it easier to fit in with dentistry students } \\
\text { than I do. }\end{array}$} & $\begin{array}{c}40 \% \\
(39.8 \%)\end{array}$ & $\begin{array}{c}46.7 \% \\
(38.1 \%)\end{array}$ & $\begin{array}{l}10 \% \\
(9.7 \%)\end{array}$ & $\begin{array}{l}3.3 \% \\
(9.7 \%)\end{array}$ & $\begin{array}{c}0 \% \\
(2.7 \%)\end{array}$ & 1.97 \\
\hline & Never & \multicolumn{2}{|c|}{$\begin{array}{l}1 \text { or } 2 \text { times \& } \\
\text { a couple of } \\
\text { times per year }\end{array}$} & \multicolumn{2}{|c|}{$\begin{array}{l}>1 \text { time } \\
\text { per month }\end{array}$} & Weekly \\
\hline \multicolumn{7}{|l|}{ How often have you observed unequal treatment... } \\
\hline $\begin{array}{l}\text { of a patient by a student provider based on the patient's } \\
\text { sexual orientation. }\end{array}$ & $\begin{array}{c}66.7 \% \\
(83.9 \%)\end{array}$ & \multicolumn{2}{|c|}{$\begin{array}{c}30 \% \\
(16.2 \%)\end{array}$} & \multicolumn{2}{|c|}{$\begin{array}{l}3.3 \% \\
(.9 \%)\end{array}$} & $0 \%$ \\
\hline \multirow[t]{2}{*}{$\begin{array}{l}\text { of a health care provider by a patient based on the } \\
\text { provider's sexual orientation. }\end{array}$} & $\begin{array}{c}80 \% \\
(94.6 \%)\end{array}$ & \multicolumn{2}{|c|}{$\begin{array}{c}17 \% \\
(4.5 \%)\end{array}$} & \multicolumn{2}{|c|}{$\begin{array}{l}3.3 \% \\
(.9)\end{array}$} & $0 \%$ \\
\hline & 1 & 2 & 3 & 4 & 5 & Mean \\
\hline \multicolumn{7}{|l|}{ Factor 5: student experiences/observations } \\
\hline $\begin{array}{l}\text { There are many unwritten rules concerning how one is } \\
\text { expected to interact with peers. }\end{array}$ & $\begin{array}{l}3.3 \% \\
(5.3 \%)\end{array}$ & $\begin{array}{c}10 \% \\
(15.9 \%)\end{array}$ & $\begin{array}{l}43.3 \% \\
(30.1 \%)\end{array}$ & $\begin{array}{l}43.3 \% \\
(34.5 \%)\end{array}$ & $\begin{array}{c}0 \% \\
(13.3 \%)\end{array}$ & 3.35 \\
\hline \multirow[t]{2}{*}{$\begin{array}{l}\text { Some students have a condescending attitude toward } \\
\text { members of this group. }\end{array}$} & $\begin{array}{c}0 \% \\
(7.1 \%)\end{array}$ & $\begin{array}{c}10 \% \\
(20.5 \%)\end{array}$ & $\begin{array}{l}63.3 \% \\
(21.4 \%)\end{array}$ & $\begin{array}{l}23.3 \% \\
(41.1 \%)\end{array}$ & $\begin{array}{l}3.3 \% \\
(9.8 \%)\end{array}$ & 3.26 \\
\hline & Never & \multicolumn{2}{|c|}{$\begin{array}{l}1 \text { or } 2 \text { times \& } \\
\text { a couple of } \\
\text { times per year }\end{array}$} & \multicolumn{2}{|c|}{$\begin{array}{l}>1 \text { time } \\
\text { per month }\end{array}$} & Weekly \\
\hline
\end{tabular}

\section{Factor 6: frequency of observed discrimination}

Within the last year how often have you overheard insensitive or disparaging comments about sexual minorities (including lesbian, gay, bisexual, transgender, or transsexual individuals) or about particular persons as "typical" of sexual minorities . .

$\begin{array}{lcccc}\text { from faculty } & 43.3 \% & 53.3 \% & 0 \% & 0 \% \\ & (80.6 \%) & (8.4 \%) & (0 \%) & (1 \%) \\ \text { from students } & 13.3 \% & 80 \% & 6.7 \% & 0 \% \\ & (31.9 \%) & (50 \%) & (15 \%) & (7.1 \%) \\ \text { from staff } & 60 \% & 40 \% & 0 \% & 0 \% \\ & (83.9 \%) & (9.8 \%) & (5.4 \%) & (.9 \%)\end{array}$

Note: If percentages do not add up to $100 \%$, there are missing data in these responses.

Answers were given on five-point answer scales with $1=$ disagree strongly, $2=$ disagree, $3=$ neutral, $4=$ agree, and $5=$ agree strongly . The school-based average responses were categorized: $\langle 1.5=1 ; 1.5-2.5=2 ;>2.5-3.5=3 ;>3.5-4.5=4 ;>4.5=5$.

The individual responses (as opposed to the school-level responses) are in parentheses.

percent) or strongly agreed (3.3 percent) with the two statements that the school environment is one in which LGBT students are comfortable and are included and that the dental school administration creates a positive environment for students with non-heterosexual orientations (agreed: 63.3 percent). Respondents from five of the thirty schools disagreed (13.3 percent) or strongly disagreed (3.3 percent) with the statement that LGBT students voice their ideas in meetings and classes as often as students with heterosexual orientations, and students from 30 percent of the schools responded neutrally to these statements.
General perceptions of discrimination (items loading on Factor 4) were reported as being rather infrequent. Respondents from only one school perceived unequal treatment of patients by student providers based on the patient's sexual orientation or unequal treatment of providers by patients with a different sexual orientation more than one time per month. The majority reported to have never observed that a patient from an LGBT background (66.7 percent) or a provider from an LGBT background ( 80 percent) suffered discrimination. However, student leaders from 26.6 percent of the schools agreed or strongly agreed with the statement that some students 
have a condescending attitude towards members of the LGBT community, while respondents from 63.3 percent of the schools responded in a neutral fashion to this statement.

When asked to look back over the previous year and consider whether the respondents had overheard disparaging or insensitive comments about sexual minorities from faculty or staff members or from students, student leaders at only two schools reported having heard such comments more than once per month from students (6.7 percent). However, students from 80 percent of the schools reported that they had heard these remarks from students once or twice, or a couple of times per year. When asked about the frequency of such remarks by faculty and staff members, student leaders from 53.3 percent of the schools reported to have heard such remarks from faculty members one or two times per year, and respondents from 40 percent of the schools reported that they had overheard such remarks from staff members once or twice per year.

A hypothesis one might deduce from the research reviewed in the introduction to this article could be that educational efforts concerning LGBT issues and LGBT-related climate issues are related. ${ }^{5}$ In order to analyze whether these relationships exist, the responses to the items loading on each of the six factors were averaged to create indices. Table 4 provides an overview of the correlations between individual student leaders' responses concerning LGBT-related educational experiences and the general cultural climate in their schools and the six indices capturing their perceptions and experiences concerning LGBT issues in their schools.

The degree to which individual students agreed with the statement "My classes prepared me well for treating patients from non-heterosexual backgrounds" correlated significantly with their responses

Table 4. Correlations between the students' responses concerning LGBT-related educational experiences and the general cultural climate and the LGBT-specific climate and observations

\begin{tabular}{|c|c|c|c|c|}
\hline & $\begin{array}{l}\text { My classes } \\
\text { prepared me } \\
\text { well for treating } \\
\text { patients from } \\
\text { non-heterosexual } \\
\text { backgrounds. }\end{array}$ & $\begin{array}{l}\text { The curriculum } \\
\text { should include } \\
\text { more education } \\
\text { about treating } \\
\text { patients from } \\
\text { non-heterosexual } \\
\text { backgrounds. }\end{array}$ & $\begin{array}{l}\text { I believe that } \\
\text { my university } \\
\text { has an honest } \\
\text { interest/concern } \\
\text { for diversity on } \\
\text { this campus. }\end{array}$ & $\begin{array}{l}\text { I believe that } \\
\text { my dental } \\
\text { school has } \\
\text { an honest } \\
\text { interest/concern } \\
\text { for diversity in } \\
\text { the dental school. }\end{array}$ \\
\hline $\begin{array}{l}\text { My classes prepared me well for treating } \\
\text { patients from non-heterosexual backgrounds. }\end{array}$ & 1 & $\begin{array}{c}-.191 \\
p=.043\end{array}$ & $\begin{array}{c}.391 \\
p<.001\end{array}$ & $\begin{array}{l}.327 \\
p<.001\end{array}$ \\
\hline $\begin{array}{l}\text { The curriculum should include more } \\
\text { education about treating patients from } \\
\text { non-heterosexual backgrounds. }\end{array}$ & $\begin{array}{l}-.191 \\
p=.043\end{array}$ & 1 & $\begin{array}{l}-.067 \\
p=.482\end{array}$ & $\begin{array}{l}-.242 \\
p=.010\end{array}$ \\
\hline $\begin{array}{l}\text { I believe that my university has an honest } \\
\text { interest/concern for diversity on this campus. }\end{array}$ & $\begin{array}{c}.391 \\
\mathrm{p}<.001\end{array}$ & $\begin{array}{l}-.067 \\
p=.482\end{array}$ & 1 & $\begin{array}{c}.628 \\
\mathrm{p}<.001\end{array}$ \\
\hline $\begin{array}{l}\text { I believe that my dental school has an honest } \\
\text { interest/concern for diversity in the dental } \\
\text { school. }\end{array}$ & $\begin{array}{l}.327 \\
\mathrm{p}<.001\end{array}$ & $\begin{array}{l}-.242 \\
p=.010\end{array}$ & $\begin{array}{l}.628 \\
p<.001\end{array}$ & 1 \\
\hline Factor 1: general climate perceptions & $\begin{array}{c}.404 \\
\mathrm{p}<.001\end{array}$ & $\begin{array}{l}-.177 \\
p=.061\end{array}$ & - $^{*}$ & - $^{*}$ \\
\hline Factor 2: faculty and clinics and LGBT issues & $\begin{array}{c}.414 \\
\mathrm{p}<.001\end{array}$ & $\begin{array}{l}-.086 \\
p=.370\end{array}$ & $\begin{array}{c}.561 \\
\mathrm{p}<.001\end{array}$ & $\begin{array}{c}.568 \\
\mathrm{p}<.001\end{array}$ \\
\hline $\begin{array}{l}\text { Factor 3: climate for students with LGBT } \\
\text { orientations }\end{array}$ & $\begin{array}{l}.376 \\
p<.001\end{array}$ & $\begin{array}{l}-.057 \\
p=.552\end{array}$ & $\begin{array}{l}.355 \\
p<.001\end{array}$ & $\begin{array}{l}.354 \\
p<.001\end{array}$ \\
\hline Factor 4: perceptions of discrimination & $\begin{array}{c}-.250 \\
p=.008\end{array}$ & $\begin{array}{c}.238 \\
\mathrm{p}=.012\end{array}$ & $\begin{array}{c}-.304 \\
\mathrm{p}=.001\end{array}$ & $\begin{array}{l}-.381 \\
\mathrm{p}<.001\end{array}$ \\
\hline Factor 5: student experiences/observations & $\begin{array}{c}-.262 \\
p=.006\end{array}$ & $\begin{array}{c}.007 \\
p=.946\end{array}$ & $\begin{array}{c}-.181 \\
p=.058\end{array}$ & $\begin{array}{c}-.236 \\
p=.013\end{array}$ \\
\hline Factor 6: frequency of observed discrimination & $\begin{array}{c}-.260 \\
p=.009\end{array}$ & $\begin{array}{c}.138 \\
p=.167\end{array}$ & $\begin{array}{c}-.336 \\
p=.001\end{array}$ & $\begin{array}{c}-.219 \\
p=.027\end{array}$ \\
\hline
\end{tabular}

Note: The wording of the items that were used to create the six indices (factors) can be found in Table 3.

*No correlation is reported for the relationship between the Factor 1 index and this item because this item is part of Factor 1. 
to the general climate item ("I believe that my university has an honest interest/concern for diversity on campus": $\mathrm{r}=.391 ; \mathrm{p}<.001)$ and with the general dental school climate item ("I believe that my dental school has an honest interest/concern for diversity in the dental school": $\mathrm{r}=.327 ; \mathrm{p}<.001$ ). In addition, students who felt they were well prepared for treating non-heterosexual patients were much more likely to perceive a more positive general climate for LGBT individuals at their schools $(\mathrm{r}=0.404, \mathrm{p}<.001)$ and a more positive climate for LGBT students $(\mathrm{r}=.376$, $\mathrm{p}<.001$ ). The better students felt prepared, the less discrimination against LGBT students they perceived $(\mathrm{r}=-.250, \mathrm{p}=.008)$, the less they experienced and observed negative behavior against LGBT students $(\mathrm{r}=-.262, \mathrm{p}=.006)$, and the less frequently they observed discrimination of sexual minorities by faculty, students, and staff members.

In addition to exploring how dental school leaders in general perceive their dental schools' LGBT-related educational efforts and climate, the study also explored how student leaders who selfidentified as LGBT differed in their perceptions and experiences from students who did not identify as LGBT (see Table 5). Sixteen of the 112 respondents self-identified as LGBT. A comparison of the responses of these sixteen persons with the responses of the ninety-seven student leaders who did not self-identify as LGBT showed several significant differences. Compared to non-LGBT student leaders, self-identified LGBT student leaders agreed more strongly with the statement "The curriculum should include more education about treating patients from non-heterosexual backgrounds" (on a scale from $1=$ strongly disagree to $5=$ strongly agree: non-LGBT respondents $=2.50$ versus LGBT respondents $=3.31$; $\mathrm{p}=.008)$. LGBT respondents were significantly less comfortable working in their dental school compared to non-LGBT respondents (3.75 vs. $4.64 ; \mathrm{p}=.013$ ), and agreed less with the statement "It is easy to feel comfortable in this school for persons regardless of their sexual orientation" (LGBT $=3.13$ versus nonLGBT=3.93; $\mathrm{p}=.054)$. LGBT respondents agreed more strongly with the statement "There are many unwritten rules concerning how one is expected to interact with peers" compared to non-LGBT respondents (3.94 vs. $3.25 ; \mathrm{p}=.018)$.

Concerning the climate for student leaders from LGBT backgrounds, LGBT students agreed less strongly than non-LGBT students with the statements "Faculty encourage students equally to pursue career development independent of their sexual orientation" (3.44 vs. 4.14; $\mathrm{p}=.011)$ and "The dental school administration creates a positive environment for students with non-heterosexual orientations" (3.13 vs. 3.69; $p=.018$ ). In addition, LGBT student leaders agreed more strongly than non-LGBT respondents with the statement "Others seem to find it easier to fit in with dentistry students than I do" (3.12 vs. 1.77; $\mathrm{p}<.001$ ). LGBT respondents tended to observe more frequently unequal treatment of a patient by a student provider based on the patient's sexual orientation ( 1.33 vs. $1.02 ; p=.071)$, and they perceived more often unequal treatment of a health care provider by a patient based on the provider's sexual orientation ( 1.40 vs. $1.07 ; p=.028)$ compared to non-LGBT respondents. In summary, self-identified LGBT student leaders differed substantially in some of their perceptions and experiences from non-LGBT dental student leaders.

\section{Discussion}

In 2004, More et al. published the results of a survey of academic affairs administrators concerning their perceptions of LGBT issues in their dental schools. ${ }^{4}$ As a complement to the study by More et al., our research focused on the LGBT-related perceptions and experiences of student leaders in U.S. and Canadian dental schools. These respondents were recruited indirectly by asking administrators at fifty-two U.S. and ten Canadian dental schools to forward to their student leaders a recruitment email with the link to the survey. Student leaders from thirty of the sixty-two targeted schools responded. Because of this recruitment strategy, it is unclear if the student leaders in the other thirty-two schools did not respond because they had not received an email from their administrators or if they did not respond to the email they received.

Student leaders in twenty-seven of the thirty schools from which responses were received attend U.S. dental schools (response rate for U.S. dental schools: twenty-seven of fifty-two schools; 51.9 percent) and student leaders from three schools in Canada responded (response rate: three of ten schools; 30 percent). Because of the small number of responses from the Canadian schools, the responses from the two countries were combined and analyzed together.

In addition, the numbers of respondents from each of the thirty schools varied widely from one or two responses from thirteen schools to twenty-four 
Table 5. Average responses of students who self-identified vs. did not identify as LGBT

Educational Responses

My classes prepared me well for treating patients from non-heterosexual backgrounds.*

$\begin{array}{ccc}\text { LGBT } & \text { Not LGBT } & p \\ 2.69 & 3.04 & .209 \\ 3.31 & 2.50 & .008 \\ 1.69 & 2.19 & .151\end{array}$

The curriculum should include more education about treating patients from non-heterosexual backgrounds.*

$1.69 \quad 2.19$

.151

Factor 1: general climate perceptions

I believe that my university has an honest interest/concern for diversity on this campus. ${ }^{*} \quad 4.00$

I believe that my dental school has an honest interest/concern for diversity in the dental school.* 3.69

4.04

I am comfortable working in my dental school.*

I feel comfortable working with my supervisor/instructor/patients and other students regardless of sexual orientation.*

It is easy to feel comfortable in this school for persons regardless of their sexual orientation.*

\section{Factor 2: faculty and clinics and LGBT issues}

The school clinics provide an environment for patients that is sensitive and affirming to

The faculty provides equal treatment of patients independent of the patients' sexual orientation.* 4.06

Faculty encourage students equally to pursue career development independent of their sexual orientation.

Some faculty members have a condescending attitude toward members of this group.*

\section{Factor 3: climate for students with LGBT orientations}

There is a supportive student community for these students.*

$\begin{array}{lll}2.94 & 3.11 & .666 \\ 3.13 & 3.78 & .108 \\ 3.38 & 3.54 & .674 \\ 3.13 & 3.69 & .018\end{array}$

The school environment is one in which these students feel comfortable and are included.*

These students voice their ideas in meetings and classes as often as students not belonging to this group.*

The dental school administration creates a positive environment for students with non-heterosexual orientations.*

\section{Factor 4: perceptions of discrimination}

Others seem to find it easier to fit in with dentistry students than I do.*

$\begin{array}{lll}3.12 & 1.77 & <.001 \\ & & \\ 1.33 & 1.02 & .071 \\ 1.40 & 1.07 & .028\end{array}$

How often have you observed unequal treatment. . .

of a patient by a student provider based on the patient's sexual orientation.**

of a health care provider by a patient based on the provider's sexual orientation. ${ }^{* *}$

\section{Factor 5: student experiences/observations}

$\begin{array}{llll}\text { There are many unwritten rules concerning how one is expected to interact with peers. }{ }^{*} & 3.94 & 3.25 & .018\end{array}$

Some students have a condescending attitude toward members of this group.* $\quad 3.50 \quad 3.24 \quad .506$

\section{Factor 6: frequency of observed discrimination}

Within the last year how often have you overheard insensitive or disparaging comments about sexual minorities (including lesbian, gay, bisexual, transgender, or transsexual individuals) or about particular persons as "typical" of sexual minorities . . .

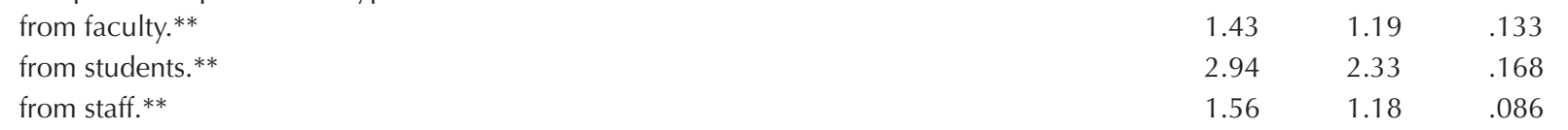

*The answers to these questions were given on five-point answer scales ranging from $1=$ disagree strongly to $5=$ agree strongly.

**The answers to these questions were given on five-point answer scales as follows: $1=$ never, $2=1$ or 2 times, $3=$ couple of times per year, $4=$ greater than once a month, and $5=$ weekly. 
responses in one school. As described above, the responses of the student leaders in any given school were averaged so that the data could be analyzed on a school level. This procedure ensured that the responses for each school were weighted equally, and it prevented an unequal representation of schools in the description of the findings. However, when the relationships between the perceived educational efforts and the climate were analyzed, individual responses were used to investigate if such a relationship existed in the minds of any member of a dental school community.

The first objective was to assess the educational efforts concerning LGBT issues. This objective was approached by first asking two closed-ended questions-how well the respondents feel prepared to treat patients from non-heterosexual backgrounds and whether the curriculum should include more education about this topic - and second, to then let the respondents give an open-ended answer to the question asking in which classes they had learned about this topic. The responses to the closed-ended questions showed that while respondents from four schools perceived that they were well prepared to treat patients from LGBT backgrounds, students from a majority of participating schools indicated they were not optimally prepared. This finding together with the fact that respondents from twenty-three of the thirty schools could not recollect any classes in which they had received information about LGBT issues should alert all dental school administrators to reflect on their own curricula. Not having any LGBT curriculum content might send a negative message to the dental school community, because silence could be seen as indicative of negativity toward the subject matter. ${ }^{10}$

Given that the respondents described their education as less than optimal, it is surprising that not more students said they would like to have more LGBT-related education. One interpretation of this finding could be that because there is currently a lack of LGBT information, some student leaders may not be aware of educational and clinical issues pertinent to the LGBT community. This interpretation is in line with the finding that LGBT self-identified respondents who may be more aware of the situation wanted more curriculum content than their non-LGBT counterparts. This result could, on one hand, be due to the self-identified LGBT respondents' own desire to know more; but, on the other hand, it could also reflect their desire to have better educated colleagues. In 2004, Fikar and Keith found that LGBT-identified health care workers desired specific information about the LGBT population and desired more LGBTfriendly ways of obtaining this information. ${ }^{10}$ Some of these LGBT-identified health care providers believed that neutrality and nonaction were actually negative signs, because not talking about LGBT issues cannot only be interpreted as scholarly ignorance, but it can also be a sign of purposeful ignorance concerning the subject matter.

In any case, these findings show that there is a need for many schools to reflect on their LGBTrelated curriculum content and develop strategies to improve their students' awareness and knowledge concerning LGBT issues. Several of the respondents added suggestions about how their LGBT-related education could be improved. Several suggestions focused on integrating information about patients with non-heterosexual orientations into other courses such as those that address ethics, communication, or public health issues. Another suggestion was to create a course that focuses on understanding the treatment of diverse patients and providing the most professional treatment for all patients. Other respondents suggested specific educational interventions such as bringing a panel of LGBT patients to the school, creating standardized-patient encounters, or having clinical interactions with LGBT patients.

One way to gain a better understanding of how to include LGBT information in the dental school curriculum might be to look at other professional fields and their efforts in this area. For example, the companion document to the Healthy People 2010 report that the Gay and Lesbian Medical Association published in 2001 describes concerns and issues that health providers should recognize when treating sexual minorities. ${ }^{7}$ This document can support dental school educators in identifying relevant content material.

Concerning the process of how this education should be structured, research in social work settings can provide some valuable insights. For example, in 1991, Wells evaluated the effectiveness of different ways to teach LGBT issues and found that no teaching strategy (such as showing a movie, providing information about definitions/slang terms, historical perspectives on homophobia, discussion of reactions to information, multiple films on lesbian relationships, or a panel of gay and lesbian students who answer questions) was effective by itself. ${ }^{17}$ However, he found that after the students participated in a semester-long program that included all of these forms of teaching, students' attitudes that reflected a homophobic perception decreased overall. Likewise, 
Black et al. found in 1996 that one-shot events such as one lecture or panel concerned with LGBT material will not change students' attitudes toward LGBT individuals, but that the repeated inclusion of LGBT material over the course of a social work program did significantly change attitudes. ${ }^{18}$

However, there is one study that demonstrated even a one-shot event may have sufficient impact to alter students' perceptions. In 2001, Dongvillo and Ligon reported on a study in which one of the investigators presented a lecture about social issues related to homosexuality in a social work undergraduate course and a graduate course.${ }^{19}$ In the undergraduate course, he did not disclose his homosexual identity, but in the graduate course he did. While the graduate students had more positive attitudes toward LGBT individuals than the undergraduates before the lecture, positive attitudes toward LGBT individuals increased in both groups.

Other researchers have found that attitudes might change for some members of the audience, but not for others. In 1993, Green et al. found, for example, that a panel discussion with gays and lesbians about their coming out stories was able to positively alter the attitudes of female students in the audience, but did not change the attitudes of male audience members. ${ }^{20}$ However, Chng and Moore found, using a similar gay and lesbian panel, that attitudes did not change significantly for college students in the audience after listening to the panel. ${ }^{21}$

In addition to gender, other characteristics might also affect how students respond to LGBTrelated materials. In 1997, Cramer found that social workers who self-identified as Christians, grew up in small towns, and had (knowingly) little previous contact with lesbians were likely to display the most negative professional behavior towards lesbians. ${ }^{22}$ This author showed that working as a professional in social work did not decrease negative attitudes and therefore concluded that education pertaining to LGBT issues needed to be included in the curriculum to better prepare these students for the realities of social work in the community. While increasing knowledge might be the least threatening part of curricular change compared to interventions to alter attitudes, Cramer suggested considering that knowledge will not transfer to professional behavior toward LGBT individuals unless the providers' professional attitudes are changed. ${ }^{21}$ However, changing attitudes can be challenging. Bassett and Day, for example, found in 2004 that only students who placed in the midrange level of the Attitudes toward Lesbians and Gay Scale decreased their homophobic and antigay attitudes after being taught about the LGBT population as an at-risk population. ${ }^{23}$ In 1984, Herek recommended that having positive contacts with LGBT persons might be the way to decrease negative attitudes toward LGBT-identified individuals. ${ }^{24}$

Research on instilling positive attitudes about diversity in society supports the hypothesis that lectures have the potential to enhance knowledge, but personal experiences create more positive attitudes about cultures that are unfamiliar to students..$^{25}$ Research found, for example, that education about ethnic/racial diversity in dental schools helped students to develop a feeling of cultural competence. ${ }^{26}$ In addition, the more dentists felt well prepared by their dental school programs to treat patients with special needs,${ }^{27}$ children, ${ }^{28}$ and patients on Medicaid or from underrepresented minority backgrounds, ${ }^{29}$ the more likely they were to treat these patients and have a positive attitude towards providing care for these patient populations. It would follow that if dental schools instituted curricular changes to add LGBT material, then future dental care providers may feel more comfortable treating LGBT patients. If such changes occurred, the research with social work students suggests that it should be part of preclinical instruction and then be supplemented by experiences in clinical settings.

In addition to considering how dental students could be better educated about these matters, continuing education efforts should be considered as well. One example of such efforts was a program instituted by the state of Massachusetts with the objective to improve access to health care for the LGBT population. ${ }^{30}$ This program, which consisted of a voluntary three-to-four-hour training session designed to develop a basic understanding of LGBT patients, covered such topics as provider attitudes that may conflict with providing care, specific barriers LGBT patients face when trying to access health care, and plans for implementing these standards. While unfortunately only a small number of agencies that showed interest in this effort actually followed through with implementing this training, this program could be used as a model to develop continuing education courses for dentists, dental hygienists, and dental assistants to ensure that all dental care providers might be better equipped for treating LGBT patients.

The second objective of our study was to assess student leaders' perceptions of the dental school climate concerning LGBT issues. Two findings are noteworthy. First, respondents at most schools revealed a 
more positive view of their parent university's interest/concern for diversity than of their dental school's interest/concern. These findings raise the question whether dental schools should seriously consider whether their diversity-related interests and concerns are keeping pace with the interests and concerns on their university campus at large. Second, the climaterelated findings also showed that student leaders in many schools perceive that the climate in their schools in general and in regard to LGBT individuals could be improved. In particular, the comparison of the perceptions and experiences of the self-identified LGBT students and of the students who did not self-identify themselves as LGBT should alert dental school administrators and faculty members alike to take a critical look at their school's overall environment of diversity. Overall, student leaders felt quite comfortable working in their schools, but respondents in 30 percent of the schools did not agree that it was as easy to feel comfortable in their school for LGBT students, indicating a perception among student leaders that LGBT individuals might feel uncomfortable in dental school environments. In addition, only one-fifth of the students thought that there was a supportive student community for LGBT-identified students, and only half of the students thought that LGBT students were involved members of their schools. Compared to non-LGBT-identified student leaders, the self-identified LGBT students felt significantly less comfortable working in their schools, thought that non-LGBT students had an easier time fitting in, and agreed more strongly with the statement that there were unwritten rules concerning how one is expected to act with peers.

The fact that the climate-related responses were not quite as positive is of particular interest because of the significant relationships between the perceived quality of LGBT-related education and the climate in dental schools. These relationships should alert dental school administrators to the possibility that educational efforts and climate issues might go hand in hand. Educating students about how to treat patients with LGBT orientations in a professional manner might affect the climate in a school as well. Ultimately, any discrimination against a member of the dental school community, whether it involves a patient, a student, a staff member, or a faculty member, will damage the community as a whole by undermining a sense of commitment to and trust in an institution. Creating a supportive environment in which individuals from all different backgrounds feel respected and included will allow all members of the community to live up to their potential and will thus make the community at large a better place for everybody.

\section{Conclusions}

We can draw the following conclusions from our study.

First, the student leaders in 87.7 percent of the thirty dental schools responding strongly disagreed, disagreed, or responded neutrally to the statement that their classes prepared them well for treating patients from non-heterosexual backgrounds. This finding together with the finding that student leaders in twenty-three of the thirty schools could not list any classes in which they received information about treating LGBT patients indicates that education pertinent to LGBT health care issues needs to be increased in dental school.

Second, two conclusions can be drawn concerning students' perceptions of the dental school climate. First, while respondents from all but one dental school indicated that their university has an honest interest/concern for diversity, the respondents in seven of the thirty schools did not agree that their own dental school had a similar interest/concern for diversity. Considering these results, one potential conclusion could be that not all dental school faculty members follow the lead of their central administration to provide a culturally sensitive environment in general. The finding concerning the responses to a LGBT-specific item - that their dental school administration creates a positive environment for students with non-heterosexual orientations - supports this general conclusion. Respondents from 36.7 percent of the thirty schools did not agree with this statement. Second, while student leaders from only one school perceived open discrimination of a patient or provider because of their sexual orientation more than one time per month, the responses overall showed that discriminatory remarks were observed infrequently.

Third, the significant correlations between the responses to the educational statement and the climate-related responses point to the importance of understanding that educational efforts are linked to the climate in a given school. Progress has to be made on both fronts, with curricular efforts going hand in hand with climate-related efforts. One LGBT climate-related effort is, for example, the existence of an LGBT student group in a dental school. 
Fourth, the comparison of the responses of self-identified versus non-self-identified LGBT student leaders found that LGBT respondents did not perceive themselves as playing on an equal playfield. Compared to non-LGBT respondents, LGBT respondents felt less comfortable in their school, perceived that they had a more difficult time fitting in, and sensed that they had to follow more unwritten rules. In addition, LGBT respondents perceived more discrimination and less support compared to non-LGBT respondents.

\section{REFERENCES}

1. Laumann EO, Gagnon JH, Michael RT, Michaels S. The social organization of sexuality: sexual practices in the United States. Chicago: University of Chicago Press, 1994.

2. Smith DM, Gates GJ. Gay and lesbian families in the United Sates: same-sex unmarried partner households. Washington, DC: Human Rights Campaign Report, 2001.

3. Cooke RA, Rousseau DM. Behavioral norms and expectations: a quantitative approach to the assessment of organizational culture. Group \& Organization Management 1988;13(3):245-73.

4. More FG, Whitehead AW, Gonthier M. Strategies for student services for lesbian, gay, bisexual, and transgender students in dental schools. J Dent Educ 2004;68(6):62332.

5. Machen JB. Policy for diversity: examples from gay men and lesbian inclusion. J Dent Educ 1995;59(12):11113.

6. Townsend MH, Wallick MM, Cambre KM. Follow-up survey of support services for lesbian, gay, and bisexual medical students. Acad Med 1996;71(9):1012-4.

7. Gay and Lesbian Medical Association and LGBT health experts. Healthy People 2010 companion document for lesbian, gay, bisexual, and transgender (LGBT) health. San Francisco: Gay and Lesbian Medical Association, 2001.

8. Ridner SL, Frost K, LaHoie AS. Health information and risk behaviors among lesbian, gay, and bisexual college students. J Am Acad Nurse Practitioners 2006;18(8):3748.

9. Boehmer U. Twenty years of public health research: inclusion of lesbian, gay, bisexual, and transgender populations. Am J Public Health 2002;92(7):1125-30.

10. Fikar C, Keith L. Information needs of gay, lesbian, bisexual, and transgendered health care professionals: results of an Internet survey. J Med Libr Assoc 2004;92(1):56-65.

11. Dinkel S, Patzel B, McGuire M, Rolfs E, Purcell K. Measures of homophobia among nursing students and faculty: a Midwestern perspective. Int J Nurs Educ Scholarship 2007;4(1):art. 24.

12. Cant B. Exploring the implications for health professionals of men coming out as gay in healthcare settings. Health Social Care Community 2005;14(1):9-16.
13. McKelvey RS, Webb JA, Baldassar LV, Robinson SM, Riley G. Sex knowledge and sexual attitudes among medical and nursing students. Aust N Z J Psychiatry 1999;33:260-6.

14. Elam CL, Johnson MMS, Wiggs JS, Messmer JM, Brown P, Hinkley R. Diversity in medical schools: perceptions of first-year students at four southeastern U.S. medical schools. Acad Med 2001;76(1):60-5.

15. Inglehart MR, Quiney C, Kotowicz W, Tedesco L, Getchell $\mathrm{K}$, Jordan J, et al. Cultural audits: introduction, process, and results. J Dent Educ 1997;60:283-8.

16. Taylor GW, Inglehart MR, Lopez P, Malley J, May KB, Polverini P, et al. Dental faculty, staff, and students' experiences with diversity: a comparison of the 1994/95 and 2006/07 results of a cultural audit. Presented at the 2008 American Dental Education Association Annual Session, Dallas, TX, March 2008.

17. Wells J. What makes a difference? Various teaching strategies to reduce homophobia. Ann Sex Res 1991;11:229 38 .

18. Black B, Oles T, Moore L. Homophobia among students in social work programs. J Baccel Soc Work 1996;2:2341.

19. Dongvillo J, Ligon J. Exploring the effectiveness of teaching techniques with lesbian and gay content in the social work curriculum. J Baccel Soc Work 2001;6:115-24.

20. Green S, Dixon P, Gold-Neil V. The effects of a gay/lesbian panel discussion on college student attitudes toward gay men, lesbians, and persons with AIDS. J Sex Educ Therapy 1993;19:47-63.

21. Chng CL, Moore A. Can attitudes of college students towards AIDS and homosexuality be changed in six weeks? Health Values 1991;15:41-9.

22. Cramer E. Effects of an educational unit about lesbian identity development and disclosure in a social work methods course. J Soc Work Educ 1997;33:467-79.

23. Bassett J, Day KA. Test of the infusion method: empathetic inclusion of material on gay men in a core course. J Teach Soc Work 2004;23(3):29-40.

24. Herek GM. Beyond "homophobia": a social-psychological perspective on attitudes toward lesbians and gay men. J Homosexuality 1984;10(1/2):1-21.

25. Yuen F, Pardeck J. Impact of human diversity education on social work students. Int J Adolesc Youth 1998;7:249_ 61 .

26. Novak KF, Whitehead AW, Close JM, Kaplan AL. Students' perceived importance of diversity exposure and training in dental education. J Dent Educ 2004;68(3):355-60.

27. Dao LP, Zwetchkenbaum S, Inglehart MR. General dentists and special needs patients: does dental education matter? J Dent Educ 2005;69(10):1107-15.

28. Rich JP III, Straffon L, Inglehart MR. General dentists and pediatric dental patients: the role of dental education. J Dent Educ 2006;70:1308-15.

29. Smith CS, Ester TV, Inglehart MR. Dental education and care for underserved patients: an analysis of students' intentions and alumni behavior. J Dent Educ 2006;70(4):398-408.

30. Clark ME, Landers S, Linde R, Sperber J. The GLBT health access project: a state-funded effort to improve access to care. Am J Public Health 2001;91(6):895-96. 